\title{
Electrochemical Investigations into the Binding of Some Non-Redox Active Metal Ions to Surface-bound Glutamic Acid Conjugates.
}

\author{
Francis E. Appoh and Heinz-Bernhard Kraatz ${ }^{*}$
}

Department of Chemistry, University of Saskatchewan, 110 Science Place, Saskatoon, SaskatchewanS7N 5C9, Canada; kraatz@skyway.usask.ca

\section{Supplemental Information}

General Materials: All synthesis were carried out in air unless otherwise indicated. $\mathrm{CH}_{2} \mathrm{Cl}_{2}$, THF and $\mathrm{CHCl}_{3}$ (BDH; ACS grade) used for synthesis, FT-IR and electrochemistry were dried $\left(\mathrm{CaH}_{2}\right)$, and distilled under $\mathrm{N}_{2}$ prior to use. Acetone, EtOAc, $\mathrm{CH}_{3} \mathrm{CN}, \mathrm{MeOH}$, diethyl ether (BDH; ACS grade), hexanes (Fischer; HPLC grade), $\mathrm{CHCl}_{3}$ and $\mathrm{CH}_{2} \mathrm{Cl}_{2}$ used for the purpose of purification were used as received. $\mathrm{CDCl}_{3}$ and $\mathrm{CD}_{3} \mathrm{CN}$ (Aldrich) were dried by, and stored over molecular sieves (8-12 mesh; $4 \AA$ effective pore size; Fisher) before use. Ferrocene carboxylic acid (Aldrich), EDC, HOBt, H-Glu-OMe $\mathrm{HCl}$ (Aldrich), $\mathrm{Na}_{2} \mathrm{SO}_{4}, \mathrm{NaHCO}_{3}$ (VWR), Boc-GluOH, Boc-Glu(OBz)OH, Boc-Glu(OH)OBz, cystamine hydrochloride were used as received. $\mathrm{Et}_{3} \mathrm{~N}(\mathrm{BDH} ; \mathrm{ACS}$ grade) used in Fc-amino acid couplings was dried by molecular sieves when used in stoichiometric quantities. For column chromatography, a column with a width of $2.7 \mathrm{~cm}$ (ID) and a length of $45 \mathrm{~cm}$ was packed $18-22 \mathrm{~cm}$ high with $230-400$ mesh silica gel 
(VWR). For TLC, aluminum plates coated with silica gel $60 \mathrm{~F}_{254}$ (EM Science) were used.

General Peptide Coupling by Carbodiimide Method: Carbodiimide coupling composed of the carboxylic acid terminated compounds Fc-COOH, Boc-GluOH, Boc$\mathrm{Glu}(\mathrm{OBz}) \mathrm{OH}$ or Boc-Glu(OH)OBz in dry $\mathrm{CH}_{2} \mathrm{Cl}_{2}$ and 1.1 equivalents of $\mathrm{HOBt}$ and $\mathrm{EDC}$ added in succession. In a separate reaction vessel, the coupling free N-terminal amino acid/ peptide/ dendrimer (may be obtained by in situ TFA deprotection of the Boc group) was dissolved in minimal amount of dry $\mathrm{CH}_{2} \mathrm{Cl}_{2}$ and basified with the equivalent amount of $\mathrm{Et}_{3} \mathrm{~N}$. Mixing of the two reaction mixture leads to a clear solution which is stirred continuously for 18-120 hours. The work up involves the use of standard aqueous procedure involving the subsequent use of saturated $\mathrm{NaHCO}_{3}$ solution, $10 \%$ citric acid solution, saturated $\mathrm{NaHCO}_{3}$ solution followed by distilled water, collecting and drying of the organic layer to obtain the crude product. Saturated $\mathrm{NaCl}$ was used in situations were emulsions are formed.

General Boc Deprotection with TFA: For the preparation of Boc-protected higher generations and $\mathrm{Fc}$ functionalized compounds, Boc-protecting groups of precusor compounds were deprotected with TFA in DCM (1:1 v/v ratio) usually for 2 hours. The mixture was stirred initially in ice and then at room temperature. The reaction mixture is then pumped to dryness and finally neutralized with $\mathrm{Et}_{3} \mathrm{~N}$ in dry $\mathrm{CH}_{2} \mathrm{Cl}_{2}$ to afford the free N-terminal peptide for amide coupling.

General Deprotection Method by Base Hydrolysis: The -OMe and sometimes -OBz protecting groups of esters were deprotected by base hydrolysis in $\mathrm{MeOH}$. To a stirring mixture of the compound in $\mathrm{MeOH}(20 \mathrm{~mL})$ in ice, an excess equivalent amount of 
$\mathrm{NaOH}(\mathrm{aq})(20 \mathrm{~mL})$ was add and stirred at this temperature for 20 minutes. The solution was allowed to stand at room temperature for 6 hours. The progress of the reaction was determined by TLC with $10 \% \mathrm{CH}_{3} \mathrm{OH} / \mathrm{CHCl}_{3}$, acidified with $0.2 \mathrm{M} \mathrm{HCl}$ in ice and then extracted six times with ethyl acetate each time drying the organic phase with anhydrous $\mathrm{Na}_{2} \mathrm{SO}_{4}$. The solvent was removed under reduced pressure giving the crude product.

General Deprotection Method by Hydrogenolysis: Selected compounds involving the benzyl protecting groups were deprotected using hydrogenolysis. To weighed sample of the compounds in a Parr hydrogenation chamber and $10 \% \mathrm{wt} \mathrm{Pd} / \mathrm{C}$ catalyst added. Wet methanol $(50 \mathrm{~mL})$ was added and after evacuation, the bomb was pressurized with $\mathrm{H}_{2}$ to 60 psi for 18 hours. The progress of the reaction was monitored by TLC with $10 \%$ $\mathrm{CH}_{3} \mathrm{OH}$ in $\mathrm{CHCl}_{3}$.

Synthesis of [Boc-Glu(OBz)-CSA $]_{2}$ : was synthesized from coupling BocGlu(OBz)OH (6.61 g, $19.6 \mathrm{mmol})$, in $\mathrm{CH}_{2} \mathrm{Cl}_{2}(200 \mathrm{~mL})$ with cystamine- $\mathrm{HCl}(2.0 \mathrm{~g}, 8.9 \mathrm{mmol})$. The reaction was stirred continuously for 36 hours at room temperature. The crude compound purified by column chromatography $\left(\mathrm{R}_{\mathrm{f}}=0.7\right.$; EtOAc/Hex $\left./ \mathrm{CHCl}_{3}, 4: 1: 1\right)$ giving white solid. Yield $=3.8 \mathrm{~g}, 60 \%$. ${ }^{1} \mathrm{H}-\mathrm{NMR}\left(\mathrm{CDCl}_{3}, \delta\right.$ in ppm): $7.05(1 \mathrm{H}, \mathrm{s}, \mathrm{NH}), 5.67(1 \mathrm{H}, \mathrm{d}, \mathrm{J}$ $=7.1 \mathrm{~Hz}, \mathrm{NH}), 5.10\left(4 \mathrm{H}, \mathrm{s}, \mathrm{OCH}_{2}\right), 4.23\left(2 \mathrm{H}, \mathrm{m}, \mathrm{H}^{\alpha}-\mathrm{Glu}\right), 3.59\left(2 \mathrm{H}, \mathrm{m}, \mathrm{CH}_{2} \mathrm{CSA}\right), 3.48$ $\left(2 \mathrm{H}, \mathrm{m}, \mathrm{CH}_{2} \mathrm{CSA}\right), 2.47\left(4 \mathrm{H}, \mathrm{m}, \mathrm{CH}_{2}\right.$ of $\left.\mathrm{Glu}\right), 2.13\left(2 \mathrm{H}, \mathrm{m}, \mathrm{CH}_{2}\right.$ of $\left.\mathrm{Glu}\right), 1.99(2 \mathrm{H}, \mathrm{m}$, $\mathrm{CH}_{2}$ of Glu), $1.12\left(4 \mathrm{H}, \mathrm{s}, \mathrm{CH}_{2} \mathrm{CSA}\right), 1.40\left(18 \mathrm{H}, \mathrm{s}, \mathrm{CH}_{3}\right.$ of $\left.\mathrm{Boc}\right), 7.32(10 \mathrm{H}, \mathrm{s}, \mathrm{Bz})$. ${ }^{13} \mathrm{C}\left\{{ }^{1} \mathrm{H}\right\}-\mathrm{NMR}\left(\delta\right.$ in ppm, $\left.\mathrm{CDCl}_{3}\right): 173.8,172.3,171.6(\mathrm{C}=\mathrm{O}), 158.2(\mathrm{C}=\mathrm{O}$ Boc $), 139.0$, 127.9, 127.6, 127.5 (C-Bz), 79.3 (C-O Boc), 65.8 ( $\mathrm{C}^{\alpha}$ of Glu), 53.0 $\left(\mathrm{CH}_{2}-\mathrm{O}\right.$ ester), 37.9, $37.0\left(\mathrm{CH}_{2} \mathrm{CSA}\right), 29.8\left(\mathrm{CH}_{2} \mathrm{Glu}\right), 27.1,27.6\left(\mathrm{CH}_{3}-\mathrm{Boc}\right)$. 
Synthesis of [Fc-CO-GluG1(OBz)CSA $]_{2}$ 1: Coupling of Fc-COOH $(0.69 \mathrm{~g}, 3.0 \mathrm{mmol})$ with product of in-situ TFA deprotection of the Boc group of $[\mathrm{Boc}-\mathrm{Glu}(\mathrm{OBz})-\mathrm{CSA}]_{2}(1.0$ g, $1.4 \mathrm{mmol})$ in $\mathrm{CH}_{2} \mathrm{Cl}_{2}(200 \mathrm{~mL})$ gave the product $[\mathrm{Fc}-\mathrm{G} 1(\mathrm{OBz}) \mathrm{CSA}]_{2}$ 1. The crude orange product is purified by column chromatography $\left(\mathrm{R}_{\mathrm{f}}=0.6 ; 5 \% \mathrm{MeOH}\right.$ in $\left.\mathrm{CHCl}_{3}\right)$ giving an orange solid. Yield $=1.9 \mathrm{~g}, 63 \%$. HR-MS (FAB): calculated for $\mathrm{C}_{50} \mathrm{H}_{54} \mathrm{~N}_{4} \mathrm{O}_{8} \mathrm{Fe}_{2} \mathrm{~S}_{2}=1015.2154[\mathrm{M}+1]^{+}$, found $=1015.2104 .{ }^{1} \mathrm{H}-\mathrm{NMR}\left(\delta\right.$ in ppm $\left.\mathrm{CDCl}_{3}\right)$ : $7.49(2 \mathrm{H}, \mathrm{s}, \mathrm{NH}), 7.32(10 \mathrm{H}, \mathrm{s}, \mathrm{Bz}), 5.12\left(4 \mathrm{H}, \mathrm{s}, \mathrm{OCH}_{2}\right), 4.83\left(4 \mathrm{H}, \mathrm{s}, \mathrm{CH}^{\mathrm{m}} \mathrm{Cp}\right), 4.37(4 \mathrm{H}$, s, $\left.\mathrm{CH}^{\mathrm{m}} \mathrm{Cp}\right), 4.21(10 \mathrm{H}, \mathrm{s}, \mathrm{Cp}), 3.68\left(2 \mathrm{H}, \mathrm{m}, \mathrm{CH}_{2}\right.$ of $\left.\mathrm{CSA}\right), 3.47\left(2 \mathrm{H}, \mathrm{m}, \mathrm{CH}_{2}\right.$ of $\left.\mathrm{CSA}\right)$, $2.78\left(4 \mathrm{H}, \mathrm{m}, \mathrm{CH}_{2}\right.$ of $\left.\mathrm{CSA}\right), 4.80\left(2 \mathrm{H}, \mathrm{m}, \mathrm{H}^{\alpha}-\mathrm{Glu}\right), 2.59\left(4 \mathrm{H}, \mathrm{m}, \mathrm{CH}_{2}\right.$ of $\left.\mathrm{Glu}\right), 2.27(2 \mathrm{H}$, m, $\mathrm{CH}_{2}$ of Glu), 2.15 (2H, m, $\mathrm{CH}_{2}$ of Glu). ${ }^{13} \mathrm{C}\left\{{ }^{1} \mathrm{H}\right\}-\mathrm{NMR}$ ( $\delta$ in ppm, $\left.\mathrm{CDCl}_{3}\right)$ 173.8, 172.6, $171.8(\mathrm{C}=\mathrm{O}), 136.1,129.0,128.7,128.7(\mathrm{C}-\mathrm{Bz}), 75.4,71.2,70.2,68.9(\mathrm{Cp}), 67.9$ $\left(\mathrm{O}-\mathrm{CH}_{2}\right), 52.7\left(\mathrm{CH}^{\alpha}\right.$-Glu $), 38.9,38.2\left(\mathrm{CH}_{2}-\mathrm{CSA}\right), 31.0\left(\mathrm{CH}_{2}-\mathrm{Glu}\right), 27.3\left(\mathrm{CH}_{2}-\mathrm{Glu}\right)$. IR $\left(\mathrm{KBr}, \mathrm{cm}^{-1}\right.$ ): 3301 (w, NH Amide A), 3087 (CH-Fc), 3033, 2941 (m, CH), 1735 (s, C=O ester), 1628 (s, Amide I), 1531 (s, Amide II). UV-vis $\left(\mathrm{CHCl}_{3}, \lambda_{\max }\right.$ in $\mathrm{nm}, \varepsilon$ in $\left.\mathrm{cm}^{-1} \mathrm{M}^{-1}\right)$ : $442(240)$.

Synthesis of [Fc-CO-GluG1(OH)CSA $]_{2}$ 2: Base hydrolysis of $[\mathrm{Fc}-\mathrm{Gl}(\mathrm{OBz}) \mathrm{CSA}]_{2} \mathbf{1}$ $(1.10 \mathrm{~g}, 1.2 \mathrm{mmol})$ in $\mathrm{MeOH}(20 \mathrm{~mL})$ with excess equivalents of $\mathrm{NaOH}(\mathrm{aq})$ for 6 hours gave 2 . The crude product is purified by column chromatography $\left(\mathrm{R}_{\mathrm{f}}=0.6 ; 5 \% \mathrm{MeOH}\right.$ in $\mathrm{CHCl}_{3}$ ) giving an orange solid. Yield $=0.6 \mathrm{~g}, 65 \%$. HR-MS: calculated for $\mathrm{C}_{36} \mathrm{H}_{42} \mathrm{~N}_{4} \mathrm{O}_{8} \mathrm{Fe}_{2} \mathrm{~S}_{2}: 834.1137$, found: 834.1128. ${ }^{1} \mathrm{H}-\mathrm{NMR}$ ( $\delta$ in ppm, DMSO-d $\mathrm{d}_{6}$ ): 8.39 (1H, m, NH), $8.20(2 \mathrm{H}, \mathrm{m}, \mathrm{NH}), 7.51(1 \mathrm{H}, \mathrm{m}, \mathrm{NH}), 4.93(4 \mathrm{H}, \mathrm{m}, \mathrm{CH} \mathrm{Cp}), 4.33(4 \mathrm{H}, \mathrm{s}, \mathrm{CH}$ Cp), $4.20(10 \mathrm{H}, \mathrm{s}, \mathrm{Cp}), 4.11\left(2 \mathrm{H}, \mathrm{m}, \mathrm{CH}^{\alpha}-\mathrm{Glu}\right), 3.44\left(4 \mathrm{H}, \mathrm{m}, \mathrm{CH}_{2}-\mathrm{CSA}\right), 2.83(4 \mathrm{H}, \mathrm{s}$, $\mathrm{CH}_{2}$ of CSA $) 2.25\left(4 \mathrm{H}, \mathrm{m}, \mathrm{CH}_{2}\right.$ of Glu), $2.08\left(2 \mathrm{H}, \mathrm{m}, \mathrm{CH}_{2}\right.$ of Glu), $1.94\left(4 \mathrm{H}, \mathrm{m}, \mathrm{CH}_{2}\right.$ of 
Glu). ${ }^{13} \mathrm{C}\left\{{ }^{1} \mathrm{H}\right\}$-NMR ( $\delta$ in ppm, DMSO-d 6 ) 173.7, 173.4, $169.2(\mathrm{C}=\mathrm{O}), 77.9,77.0,70.8$, 69.3, 68.8 (C-Cp), $54.3\left(\mathrm{CH}^{\alpha}-\mathrm{Glu}\right), 38.8$ (C-CSA), 38.8-26.2 ( $\left.\mathrm{CH}_{2}-\mathrm{Glu}\right)$. IR ( $\left.\mathrm{KBr}, \mathrm{cm}^{-1}\right)$ : 3405 (O-H), 3297 (w, Amide A), 3091 (CH-Fc), 2941, 2831(m, CH), 1746 (s, C=O ester), 1630 (s, Amide I), 1529 (s, Amide II). UV-vis $\left(\mathrm{CHCl}_{3}, \lambda_{\max }\right.$ in $\mathrm{nm}, \varepsilon$ in $\left.\mathrm{cm}^{-1} \mathrm{M}^{-1}\right)$ : $446(220)$.

Synthesis of Boc-G2(OMe)OBz: BocGlu(OH)OBz $(2.0 \mathrm{~g}, 5.9 \mathrm{mmol})$ in $\mathrm{CH}_{2} \mathrm{Cl}_{2}(100$ $\mathrm{mL})$, was coupled to $\mathrm{H}-\mathrm{Glu}-\mathrm{OMe} \cdot \mathrm{HCl}(1.4 \mathrm{~g}, 6.5 \mathrm{mmol})$ in $\mathrm{CH}_{2} \mathrm{Cl}_{2}(50 \mathrm{~mL})$ and stirred for $48 \mathrm{hrs}$ used to afford Boc-G2(OMe)-OBz. The crude product was purified by column chromatography $\left(\mathrm{R}_{\mathrm{f}}=0.4\right.$; mixed solvents of $\left(10 \% \mathrm{MeOH}\right.$ in $\left.\mathrm{CHCl}_{3}\right)$ and $(\mathrm{EtOAc} / \mathrm{Hex}$ 2:1) in a 1:1 ratio, giving the desired compound. Yield $=2.8 \mathrm{~g}, 80 \%$. ${ }^{1} \mathrm{H}-\mathrm{NMR}\left(\mathrm{CDCl}_{3}, \delta\right.$ in ppm): $6.77(1 \mathrm{H}, \mathrm{d}, \mathrm{J}=7.2 \mathrm{~Hz}, \mathrm{NH}), 5.38(1 \mathrm{H}, \mathrm{d}, \mathrm{J}=7.2 \mathrm{~Hz}, \mathrm{NH}), 5.11\left(2 \mathrm{H}, \mathrm{q}, \mathrm{O}-\mathrm{CH}_{2}\right)$, $4.50\left(1 \mathrm{H}, \mathrm{m}, \mathrm{H}^{\alpha}-\mathrm{Glu}\right), 4.24\left(1 \mathrm{H}, \mathrm{m}, \mathrm{H}^{\alpha}-\mathrm{Glu}\right), 3.66,3.59\left(6 \mathrm{H}, \mathrm{s}, \mathrm{OCH}_{3}\right), 2.35,2.30,2.22$, $1.92\left(8 \mathrm{H}, \mathrm{m}, \mathrm{CH}_{2}\right.$ of Glu), $1.36\left(9 \mathrm{H}, \mathrm{s}, \mathrm{CH}_{3}\right.$ of $\left.\mathrm{Boc}\right) .{ }^{13} \mathrm{C}\left\{{ }^{1} \mathrm{H}\right\}-\mathrm{NMR}\left(\delta\right.$ in ppm, $\left.\mathrm{CDCl}_{3}\right)$ : 173.7, 172.6, 172.5, $172.1(\mathrm{C}=\mathrm{O}), 156.1(\mathrm{C}=\mathrm{O}$ Boc $), 135.7,129.0,128.9,128.8,(\mathrm{C}-\mathrm{Bz})$, 80.5, (C-O Boc), 67.7, $61.1\left(\mathrm{CH}_{2}-\mathrm{O}\right.$ ester $), 53.3,52.9\left(\mathrm{O}_{-} \mathrm{CH}_{3}\right)$ 52.2, 52.1, 52.0, $\left(\mathrm{C}^{\alpha}\right.$ of Glu), 34.4, 32.6, 30.7,27.6, 26.0, $25.3\left(\mathrm{CH}_{2} \mathrm{Glu}\right), 29.1\left(\mathrm{CH}_{3}-\mathrm{Boc}\right)$.

Synthesis of Boc-G2(OMe)-OH: Hydrogenolysis on $2.2 \mathrm{~g}$, (5.7 mM) of Boc-G2(OMe)$\mathrm{OBz}$ afforded Boc-G2(OMe)-OH. The final product was purified by column chromatography $\left(\mathrm{R}_{\mathrm{f}}=0.210 \% \mathrm{CH}_{3} \mathrm{OH}\right.$ in $\left.\mathrm{CHCl}_{3}\right)$. Yield $=2.4 \mathrm{~g}, 83 \%$ oily compound. ${ }^{1} \mathrm{H}-\mathrm{NMR}\left(\mathrm{CDCl}_{3}, \delta\right.$ in ppm): $9.30(1 \mathrm{H}, \mathrm{COOH}), 7.08(1 \mathrm{H}, \mathrm{d}, \mathrm{J}=7.2 \mathrm{~Hz}, \mathrm{NH}), 5.59(1 \mathrm{H}$, d, J = 7.2 Hz, NH), $4.63\left(1 \mathrm{H}, \mathrm{m}, \mathrm{CH}^{\alpha}-\mathrm{Glu}\right), 4.29\left(1 \mathrm{H}, \mathrm{m}, \mathrm{CH}^{\alpha}-\mathrm{Glu}\right), 3.75,3.68(6 \mathrm{H}, \mathrm{s}$, $\left.\mathrm{OCH}_{3}\right), 2.44\left(4 \mathrm{H}, \mathrm{m}, \mathrm{CH}_{2}\right.$ of Glu), $2.20\left(2 \mathrm{H}, \mathrm{m}, \mathrm{CH}_{2}\right.$ of Glu), $2.02\left(2 \mathrm{H}, \mathrm{m}, \mathrm{CH}_{2}\right.$ of Glu $)$, $1.44\left(9 \mathrm{H}, \mathrm{s}, \mathrm{CH}_{3}\right.$ of Boc). ${ }^{13} \mathrm{C}\left\{{ }^{1} \mathrm{H}\right\}-\mathrm{NMR}\left(\delta\right.$ in ppm, $\left.\mathrm{CDCl}_{3}\right)$ : 174.1, 172.6, 172.1, 171.9, 
$166.1(\mathrm{C}=\mathrm{O}), 156.1(\mathrm{C}=\mathrm{O}$ Boc $), 135.7,129.0,128.9,128.8,(\mathrm{C}-\mathrm{Bz}), 80.5$ (C-O Boc), 67.7, $68.9\left(\mathrm{CH}_{2}-\mathrm{O}\right.$ ester), 53.3, $52.9\left(\mathrm{O}-\mathrm{CH}_{3}\right)$ 52.2, 52.1, 52.0, ( $\mathrm{C}^{\alpha}$ of $\left.\mathrm{Glu}\right), 34.4,32.6$, 30.7, 27.6 ( $\left.\mathrm{CH}_{2} \mathrm{Glu}\right), 29.1\left(\mathrm{CH}_{3}-\mathrm{Boc}\right), 26.0,25.3\left(\mathrm{CH}_{2} \mathrm{Glu}\right)$.

Synthesis of [Boc-G2(OMe)-CSA] $]_{2}$ : Coupling of Boc-G2(OMe)-OH (2.8 g, $\left.5.5 \mathrm{mmol}\right)$ to Cystamine- $\mathrm{HCl}(0.6 \mathrm{~g}, 2.8 \mathrm{mmol})$ in $\mathrm{CH}_{2} \mathrm{Cl}_{2}(200 \mathrm{~mL})$ with continuously stirred for 36 hours at room temperature gave product $[\mathrm{Boc}-\mathrm{G} 2(\mathrm{OMe})-\mathrm{CSA}]_{2}$. The product purified by column chromatography $\left(\mathrm{R}_{\mathrm{f}}=0.4 ; 10 \% \mathrm{MeOH}\right.$ in $\left.\mathrm{CHCl}_{3}\right)$ giving white solid. Yield $=$ $2.2 \mathrm{~g}, 85 \% .{ }^{1} \mathrm{H}-\mathrm{NMR}\left(\mathrm{CDCl}_{3}, \delta\right.$ in ppm): $7.40(2 \mathrm{H}, \mathrm{s}, \mathrm{NH}), 7.00,5.84,4.53(6 \mathrm{H}, \mathrm{m}, \mathrm{NH})$, 4.15, $3.41\left(4 \mathrm{H}, \mathrm{m}, \mathrm{H}^{\alpha}-\mathrm{Glu}\right), 3.68,3.61\left(12 \mathrm{H}, \mathrm{s}, \mathrm{OCH}_{3}\right), 2.77\left(4 \mathrm{H}, \mathrm{s}, \mathrm{CH}_{2}\right.$ of $\left.\mathrm{CSA}\right), 2.36$ (4H, m, $\mathrm{CH}_{2}$ of $\left.\mathrm{Glu}\right), 2.31\left(4 \mathrm{H}, \mathrm{m}, \mathrm{CH}_{2}\right.$ of $\left.\mathrm{Glu}\right), 2.01\left(4 \mathrm{H}, \mathrm{m}, \mathrm{CH}_{2}\right.$ of $\left.\mathrm{CSA}\right), 1.99(2 \mathrm{H}, \mathrm{m}$, $\mathrm{CH}_{2}$ of Glu), $1.93\left(4 \mathrm{H}, \mathrm{m}, \mathrm{CH}_{2}\right.$ of Glu), $1.36\left(18 \mathrm{H}, \mathrm{s}, \mathrm{CH}_{3}\right.$ of Boc). ${ }^{13} \mathrm{C}\left\{{ }^{1} \mathrm{H}\right\}-\mathrm{NMR}(\delta$ in ppm, $\left.\mathrm{CDCl}_{3}\right): 173.7,172.3,162.3(\mathrm{C}=\mathrm{O}), 156.1(\mathrm{C}=\mathrm{O}$ Boc $), 80.3,(\mathrm{C}-\mathrm{O}$ Boc $), 61.3,60.7$ ( $\mathrm{C}^{\alpha}$ of Glu), 53.2, 52.3, $52.0\left(\mathrm{CH}_{2}-\mathrm{O}\right.$ ester $), 42.4,40.4,38.9,37.7\left(\mathrm{CH}_{2}, \mathrm{CSA}\right), 32.4$, 30.5, 28.7, $26.9\left(\mathrm{CH}_{2} \mathrm{Glu}\right)$.

Synthesis of [Fc-CO-GluG2(OMe $)_{2} \mathrm{CSA}_{2}{ }_{2}$ 3: TFA deprotection $[\mathrm{Boc}-\mathrm{G} 2(\mathrm{OMe})-\mathrm{CSA}]_{2}$ (2.1 g, $2.5 \mathrm{mmol})$ in $\mathrm{CH}_{2} \mathrm{Cl}_{2}(50 \mathrm{~mL})$, neutralized with $\mathrm{Et}_{3} \mathrm{~N}(0.6 \mathrm{~mL}, 8.0 \mathrm{mmol})$, coupled to $\mathrm{FcCO}-\mathrm{OBt}(1.0 \mathrm{~g}, 2.8 \mathrm{mmol})$ and stirred at room temperature for 48 hours gave the crude orange product $\left[\mathrm{Fc}-\mathrm{CO}-\mathrm{GluG} 2(\mathrm{OMe})_{2} \mathrm{CSA}\right]_{2} 3$. The product is purified by column chromatography $\left(\mathrm{R}_{\mathrm{f}}=0.6 ; 10 \% \mathrm{MeOH}\right.$ in $\left.\mathrm{CHCl}_{3}\right)$ giving an orange solid. Yield $=$ 2.0 g, $64 \%$. HR-MS (FAB): calculated for $\mathrm{C}_{50} \mathrm{H}_{64} \mathrm{~N}_{6} \mathrm{O}_{12} \mathrm{Fe}_{2} \mathrm{~S}_{2}=1116.906[\mathrm{M}+1]^{+}$, found $=1118.2669 .{ }^{1} \mathrm{H}-\mathrm{NMR}\left(\delta\right.$ in ppm $\left.\mathrm{CDCl}_{3}\right): 7.64(2 \mathrm{H}, \mathrm{t}, \mathrm{J}=5.8 \mathrm{~Hz}, \mathrm{NH}), 7.55(2 \mathrm{H}, \mathrm{d}$, $\mathrm{J}=7.6, \mathrm{NH}), 7.24(2 \mathrm{H}, \mathrm{d}, \mathrm{J}=7.8 \mathrm{~Hz}, \mathrm{NH}), 4.83\left(2 \mathrm{H}, \mathrm{m}, \mathrm{H}^{\alpha}-\mathrm{Glu}\right), 4.85\left(4 \mathrm{H}, \mathrm{s}, \mathrm{CH}^{\mathrm{o}} \mathrm{Cp}\right)$, $4.75\left(2 \mathrm{H}, \mathrm{m}, \mathrm{H}^{\alpha}-\mathrm{Glu}\right), 4.37\left(4 \mathrm{H}, \mathrm{s}, \mathrm{CH}^{\mathrm{m}} \mathrm{Cp}\right), 4.22(10 \mathrm{H}, \mathrm{s}, \mathrm{Cp}), 3.66,3.68(12 \mathrm{H}, \mathrm{s}$, 
$\left.\mathrm{OCH}_{3}\right), 3.63\left(2 \mathrm{H}, \mathrm{m}, \mathrm{CH}_{2} \mathrm{CSA}\right), 3.56\left(2 \mathrm{H}, \mathrm{m}, \mathrm{CH}_{2} \mathrm{CSA}\right), 2.82\left(4 \mathrm{H}, \mathrm{s}, \mathrm{CH}_{2} \mathrm{CSA}\right), 2.45$ $\left(8 \mathrm{H}, \mathrm{m}, \mathrm{CH}_{2}\right.$ of Glu), $2.20\left(8 \mathrm{H}, \mathrm{m}, \mathrm{CH}_{2}\right.$ of $\left.\mathrm{Glu}\right), 2.00\left(2 \mathrm{H}, \mathrm{m}, \mathrm{CH}_{2}\right.$ of $\left.\mathrm{Glu}\right) .{ }^{13} \mathrm{C}\left\{{ }^{1} \mathrm{H}\right\}-$ NMR ( $\delta$ in ppm, $\left.\mathrm{CDCl}_{3}\right)$ 173.7, 173.5, 172.7, 172.6, $171.8(\mathrm{C}=\mathrm{O}), 75.5,71.2,70.2,68.9$ (Cp), 53.1, $52.9\left(\mathrm{O}-\mathrm{CH}_{3}\right)$, 52.3, $52.1\left(\mathrm{CH}^{\alpha}\right.$-Glu $), 38.9,38.1\left(\mathrm{CH}_{2}-\mathrm{CSA}\right)$, 33.0, 30.9, 30.6, 28.4, $27.3\left(\mathrm{CH}_{2}\right.$ - Glu). IR $\left(\mathrm{KBr}, \mathrm{cm}^{-1}\right)$ : 3299, (w, br NH Amide A), 3085 (CH-Fc), 2951, 2866 (m, CH), 1739 (s, C=O ester), 1649, 1627 (s, Amide I), 1531 (s, Amide II). UV-vis $\left(\mathrm{CHCl}_{3}, \lambda_{\max }\right.$ in nm, $\varepsilon$ in $\left.\mathrm{cm}^{-1} \mathrm{M}^{-1}\right): 446(255)$.

Synthesis of [Fc-CO-GluG2(OH)-CSA $]_{2}$ 4: Base hydrolysis of $[\mathrm{Fc}-\mathrm{G} 2(\mathrm{OMe})-\mathrm{CSA}]_{2} 3$ $(1.5 \mathrm{~g}, 1.3 \mathrm{mmol})$ in $\mathrm{MeOH}(20 \mathrm{~mL})$ in ice, with an excess equivalent $\mathrm{NaOH}(\mathrm{aq})$ give the crude orange product $[\mathrm{Fc}-\mathrm{G} 2(\mathrm{OH})-\mathrm{CSA}]_{2}$ 4. The product is purified by column chromatography $\left(\mathrm{R}_{\mathrm{f}}=0.2 ; 15 \% \mathrm{MeOH}\right.$ in $\left.\mathrm{CHCl}_{3}\right)$ giving an orange solid. Yield $=0.9 \mathrm{~g}$, $64 \%$. HR-MS (FAB): calculated for $\mathrm{C}_{48} \mathrm{H}_{60} \mathrm{~N}_{6} \mathrm{O}_{12} \mathrm{Fe}_{2} \mathrm{~S}_{2}: 1088.8532[\mathrm{M}+1]^{+}$, found $=$ 1128. $8343\left([\mathrm{M}+1]^{+}+2 \mathrm{Na}^{+}\right) . \quad{ }^{1} \mathrm{H}-\mathrm{NMR}\left(\delta\right.$ in ppm DMSO-d $\left.\mathrm{d}_{6}\right): 12.40(2 \mathrm{H}$, broad, OH$)$, $8.18(2 \mathrm{H}, \mathrm{t}, \mathrm{NH}), 8.11(2 \mathrm{H}, \mathrm{d}, \mathrm{NH}), 7.84(2 \mathrm{H}, \mathrm{d}, \mathrm{NH}), 4.89\left(2 \mathrm{H}, \mathrm{s}, \mathrm{H}^{\mathrm{o}} \mathrm{Cp}\right), 4.84(2 \mathrm{H}, \mathrm{s}$, $\left.\mathrm{H}^{0} \mathrm{Cp}\right), 4.32\left(4 \mathrm{H}, \mathrm{s}, \mathrm{H}^{\mathrm{m}} \mathrm{Cp}\right), 4.33$ (2H, m, $\left.\mathrm{H}^{\alpha}-\mathrm{Glu}\right), 4.22$ (2H, m, $\left.\mathrm{H}^{\alpha}-\mathrm{Glu}\right), 4.19$ (10H, s, Cp), 2.79 (4H, m, $\left.\mathrm{CH}_{2} \mathrm{CSA}\right), 2.22\left(4 \mathrm{H}, \mathrm{m}, \mathrm{CH}_{2} \mathrm{CSA}\right), 1.95-1.02\left(12 \mathrm{H}, \mathrm{m}, \mathrm{CH}_{2} \mathrm{Glu}\right)$. ${ }^{13} \mathrm{C}\left\{{ }^{1} \mathrm{H}\right\}-\mathrm{NMR}\left(\delta\right.$ in ppm, DMSO-d 6 ) 174.6, 174.2, 172.9, 172.7, $170.1(\mathrm{C}=\mathrm{O}), 76.8\left(\mathrm{C}^{\mathrm{i}}\right)$, $70.9\left(\mathrm{C}^{\mathrm{o}}\right), 70.3$ (unsubst. $\left.\mathrm{Cp}\right), 69.2\left(\mathrm{C}^{\mathrm{m}}\right), 53.5,52.0,49.5\left(\mathrm{CH}^{\alpha}-\mathrm{Glu}\right), 38.9,37.8\left(\mathrm{CH}_{2^{-}}\right.$ CSA), 32.8-25.3 ( $\mathrm{CH}_{2}-\mathrm{Glu}$ ). IR ( $\mathrm{KBr}, \mathrm{cm}^{-1}$ ): 3313 (w, Amide A), 3085 (CH-Fc), 2935, 2859(m, CH), 1721 (s, C=O ester), 1657, 1630 (s, Amide I), 1529 (s, Amide II). UV-vis $\left(\mathrm{CHCl}_{3}, \lambda_{\max }\right.$ in $\mathrm{nm}, \varepsilon$ in $\left.\mathrm{cm}^{-1} \mathrm{M}^{-1}\right): 450(320)$.

NMR Measurements: NMR spectra were recorded on a Bruker AMX-500 spectrometer operating at $500 \mathrm{MHz}\left({ }^{1} \mathrm{H}\right)$ and $125 \mathrm{MHz}\left({ }^{13} \mathrm{C}\left\{{ }^{1} \mathrm{H}\right\}\right)$. Peak positions in both ${ }^{1} \mathrm{H}$ and ${ }^{13} \mathrm{C}$ 
spectra are reported in ppm relative to TMS. ${ }^{1} \mathrm{H}-\mathrm{NMR}$ spectra of Fc-peptides are referenced to the $\mathrm{CH}_{2} \mathrm{Cl}_{2}$ resonance ( $\delta$ 5.32) of an external standard $\left(\mathrm{CDCl}_{3} / \mathrm{CH}_{2} \mathrm{Cl}_{2}\right) .{ }^{1} \mathrm{H}$ spectra of all other compounds are referenced to the residual $\mathrm{CHCl}_{3}$ signal. $\mathrm{All}{ }^{13} \mathrm{C}\left\{{ }^{1} \mathrm{H}\right\}$ spectra are referenced to the $\mathrm{CDCl}_{3}$ signal at $\delta$ 77.23.

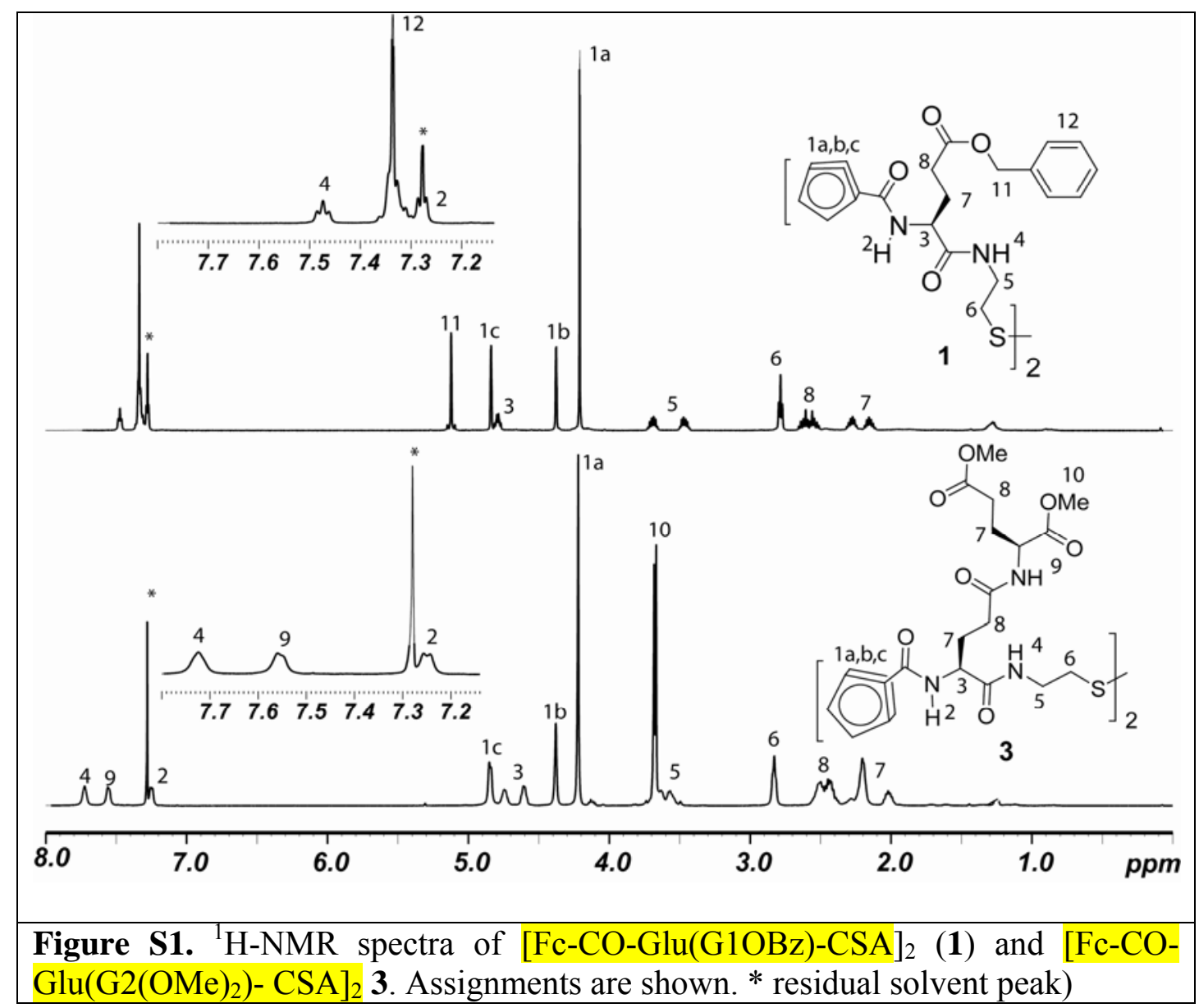


Table S1. Selected ${ }^{1} \mathrm{H}-\mathrm{NMR}$ ( $\delta$ in ppm) signals of Fc-CO-glutamic acid cystamine conjugates. Spectra for esters 1 and $\mathbf{3}$ were recorded in $\mathrm{CDCl}_{3}$ while those of the acids $\mathbf{2}$ and $\mathbf{4}$ were recorded in DMSO-d6.

\begin{tabular}{lcccc}
\hline Compounds & $\mathrm{NH}^{\mathrm{a}}$ & $\mathrm{NH}$ peptide & $\mathrm{Cp}$ & $\mathrm{CH}_{2}(\mathrm{CSA})$ \\
\hline $\mathbf{1}$ & 7.47 & 7.28 & $4.21,4.38,4.84$ & $2.78,3.47,3.68$ \\
$\mathbf{2}$ & 8.39 & 7.50 & $4.12,4.33,4.82$ & $2.82,3.43,3.86$ \\
$\mathbf{3}$ & 7.72 & $7.24,7.56$ & $4.22,4.38,4.85$ & $2.83,3.43,3.86$ \\
$\mathbf{4}$ & 8.18 & $7.84,8.11$ & $4.20,4.334 .89$ & $2.79,3.42,3.86$
\end{tabular}

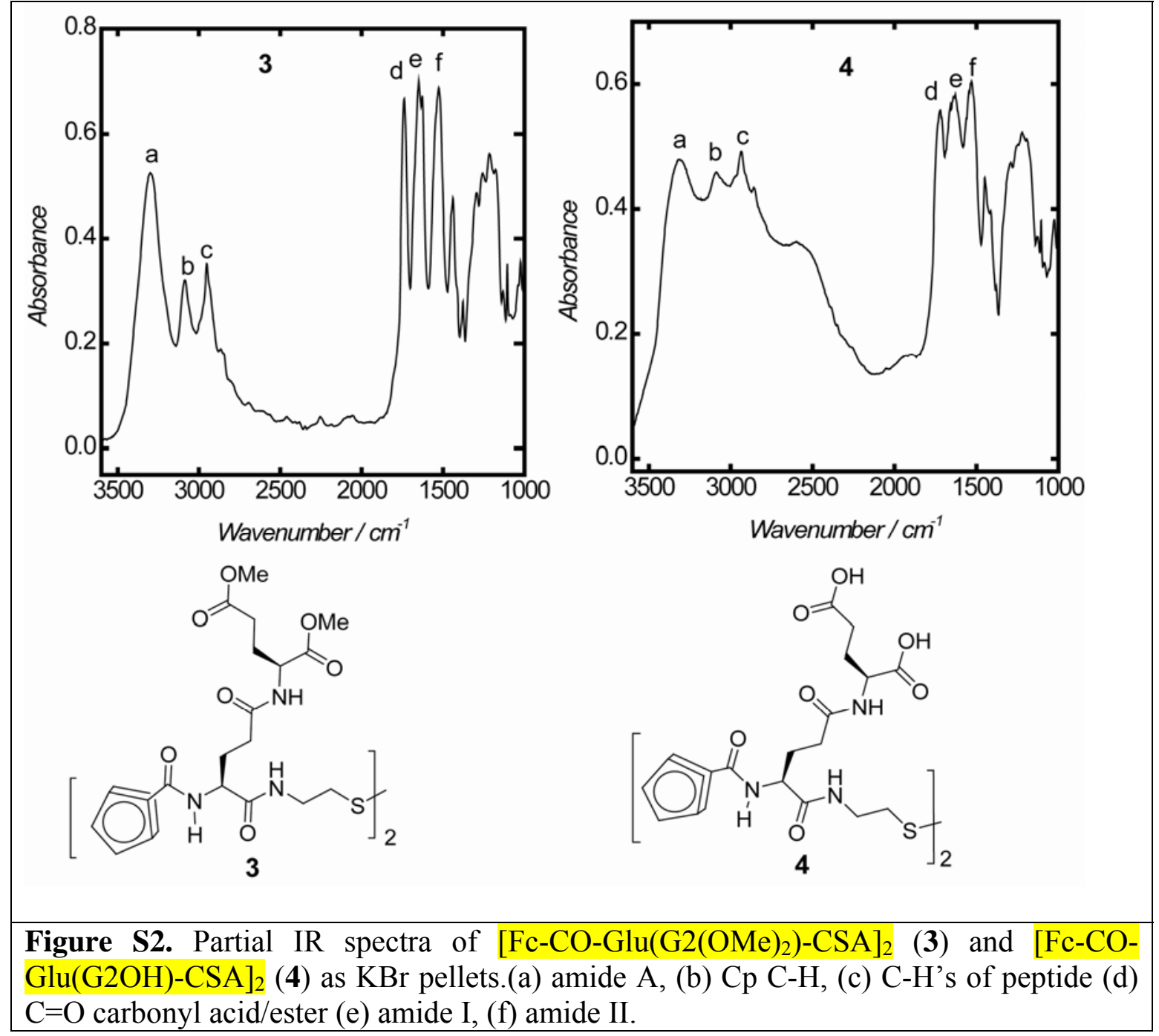


Table S2. IR and UV-vis data for Fc-CO-peptide cystamine dendrimers. IR was recorded as $\mathrm{KBr}$ disc; $\mathrm{UV}$-vis recorded in $\mathrm{MeOH}$ in the $1.0-6.0 \mathrm{mM}$ concentration range. (Resolution for IR is $4 \mathrm{~cm}^{-1}$ ) $\lambda_{\max }$ in $\mathrm{nm}, \varepsilon$ in $\mathrm{cm}^{-1} \mathrm{M}^{-1}$.

\begin{tabular}{|c|c|c|c|c|c|c|}
\hline \multirow[b]{2}{*}{ Compound } & \multicolumn{5}{|c|}{$\mathrm{IR} / \mathrm{cm}^{-1}$} & \multirow{2}{*}{$\frac{\text { UV-vis }}{\lambda_{\max }(\varepsilon)}$} \\
\hline & $\begin{array}{c}\text { Amide } \\
\text { A }\end{array}$ & $\mathrm{Cp}$ & $\mathrm{C}=\mathrm{O}$ & Amide I & Amide II & \\
\hline 1 & 3300 & 3087 & 1735 & 1627 & 1531 & $442(240)$ \\
\hline 2 & 3299 & 3091 & 1739 & 1629 & 1525 & $446(220)$ \\
\hline 3 & 3297 & 3086 & 1733 & 1629 & 1529 & $446(255)$ \\
\hline 4 & 3313 & 3086 & 1722 & 1630 & 1530 & $450(320)$ \\
\hline
\end{tabular}



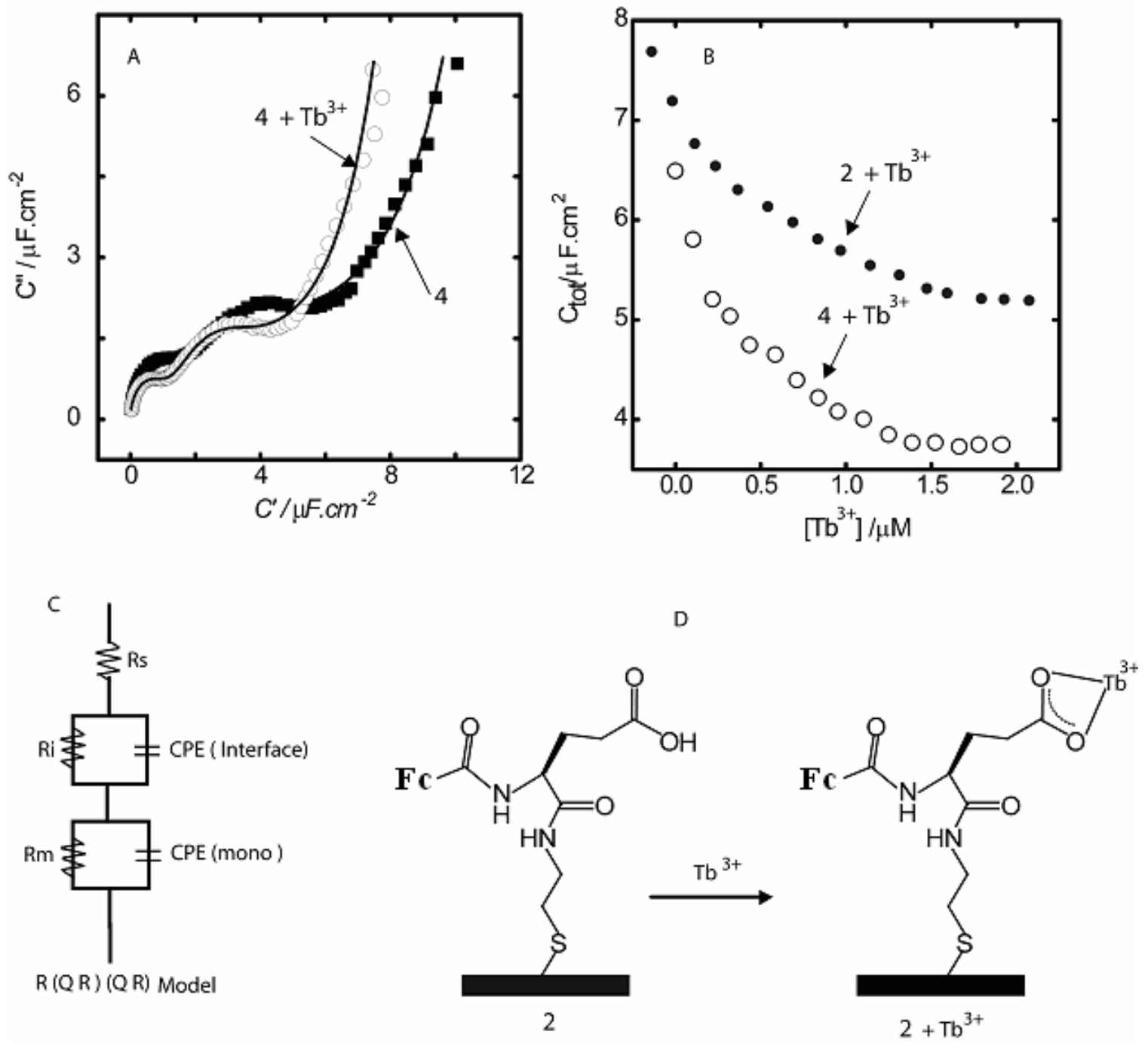

Figure S3. (A) Impedance plot in the capacitance plane $\mathbf{4}$ and $\mathbf{4}+\mathrm{Tb}^{3+}$ (continuous line is fitting to the model shown in (C), (B) Effect of $\mathrm{Tb}^{3+}$ on $\mathrm{C}_{\text {tot }}$ of films of 2 and 4, (C) Equivalent circuit for fitting. (D) Possible interaction of $\mathrm{Tb}^{3+}$ with a film of 2 . 

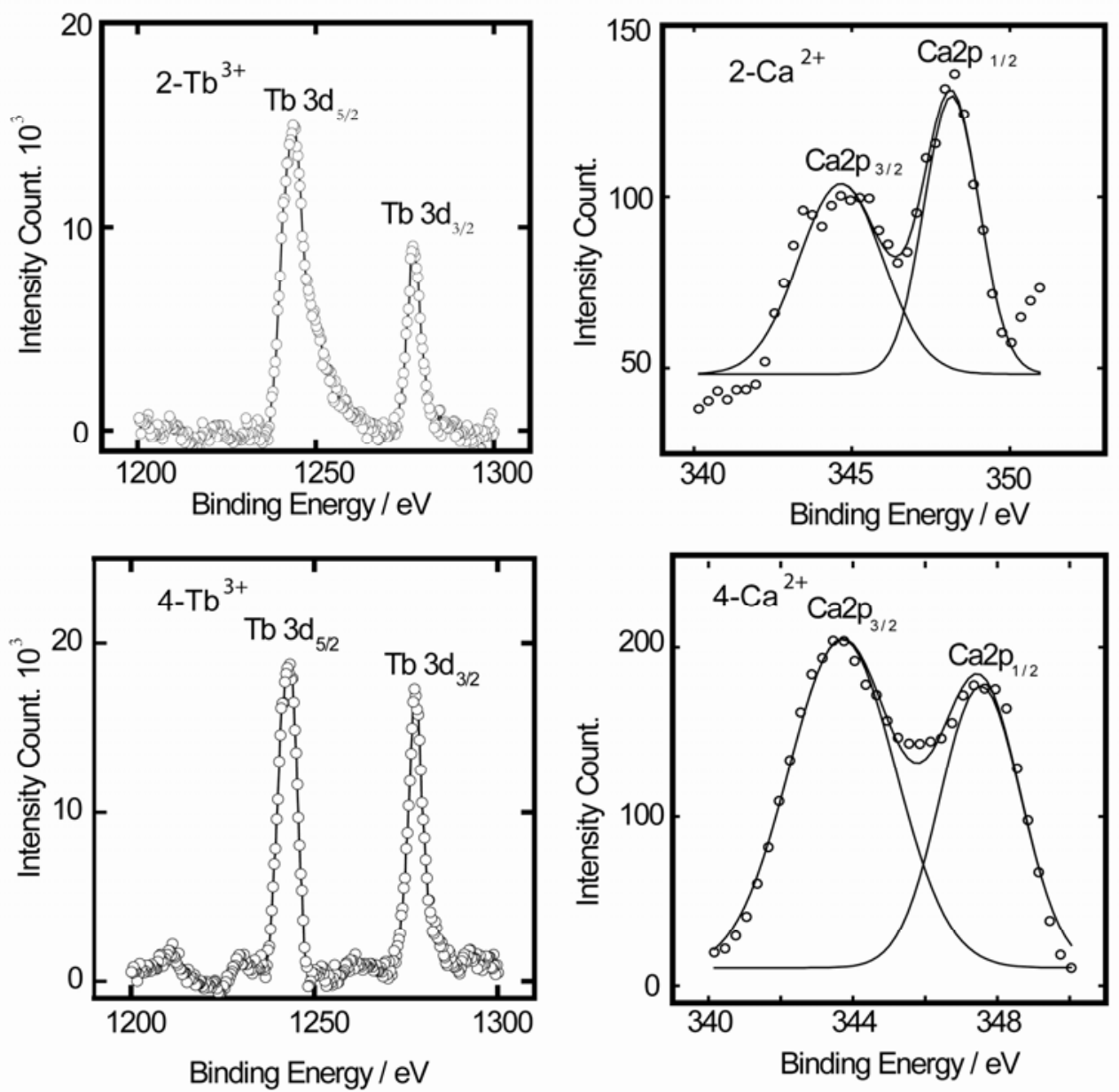

Figure S4. High resolution XPS of $\mathrm{Tb} 3 \mathrm{~d}$ and $\mathrm{Ca} 2 \mathrm{p}$ of $\mathrm{Au}$ surfaces modified with $2-\mathrm{Tb}^{3+}, 4-\mathrm{Tb}^{3+}, 2-\mathrm{Ca}^{2+}$ and $2-\mathrm{Ca}^{2+}$ films. 

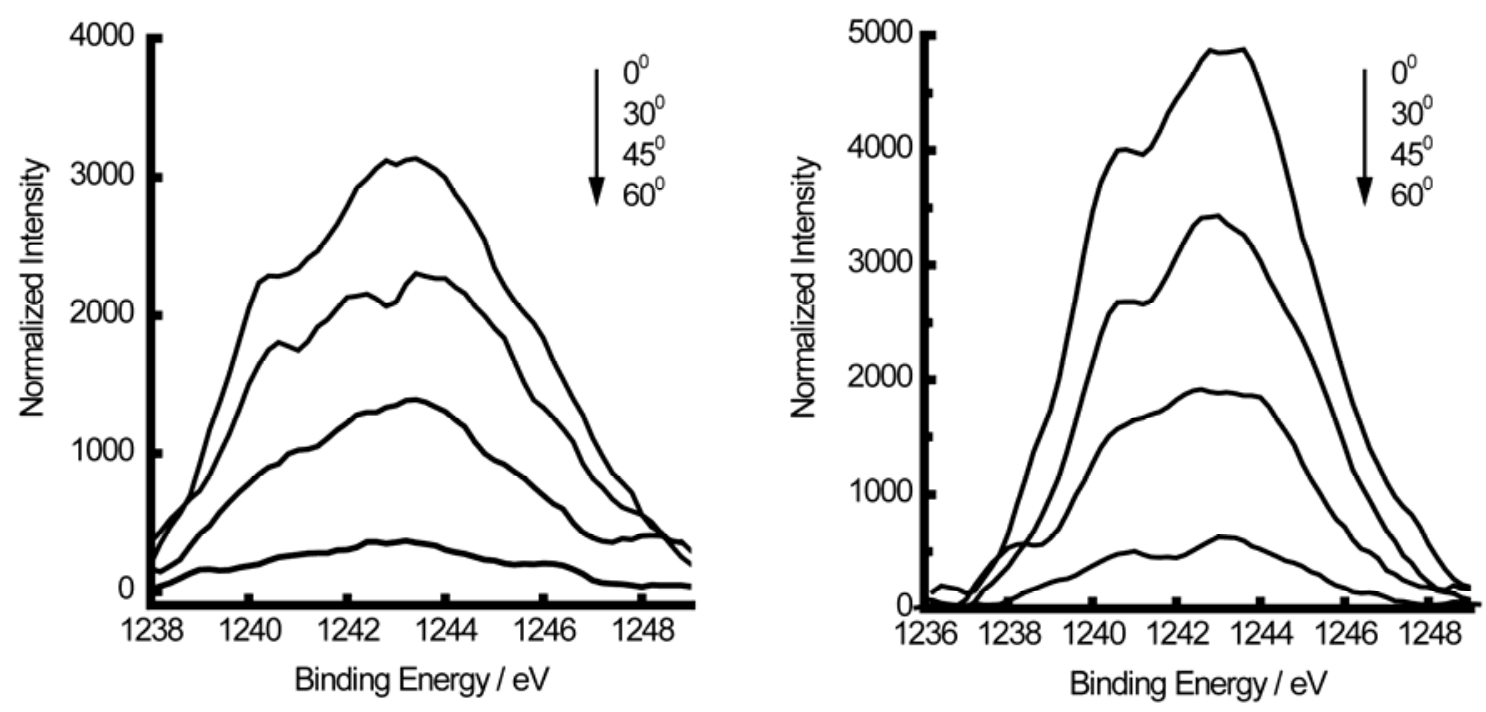

Figure S5. Normalized $\mathrm{Tb}_{3} \mathrm{~d}_{5 / 2}$ core signal intensities as a function of photoelectron detection angle. Films of $\mathbf{2}$ with $\mathrm{Tb}^{3+}$ left, and Films of $\mathbf{4}$ with $\mathrm{Tb}^{3+}$ right. 

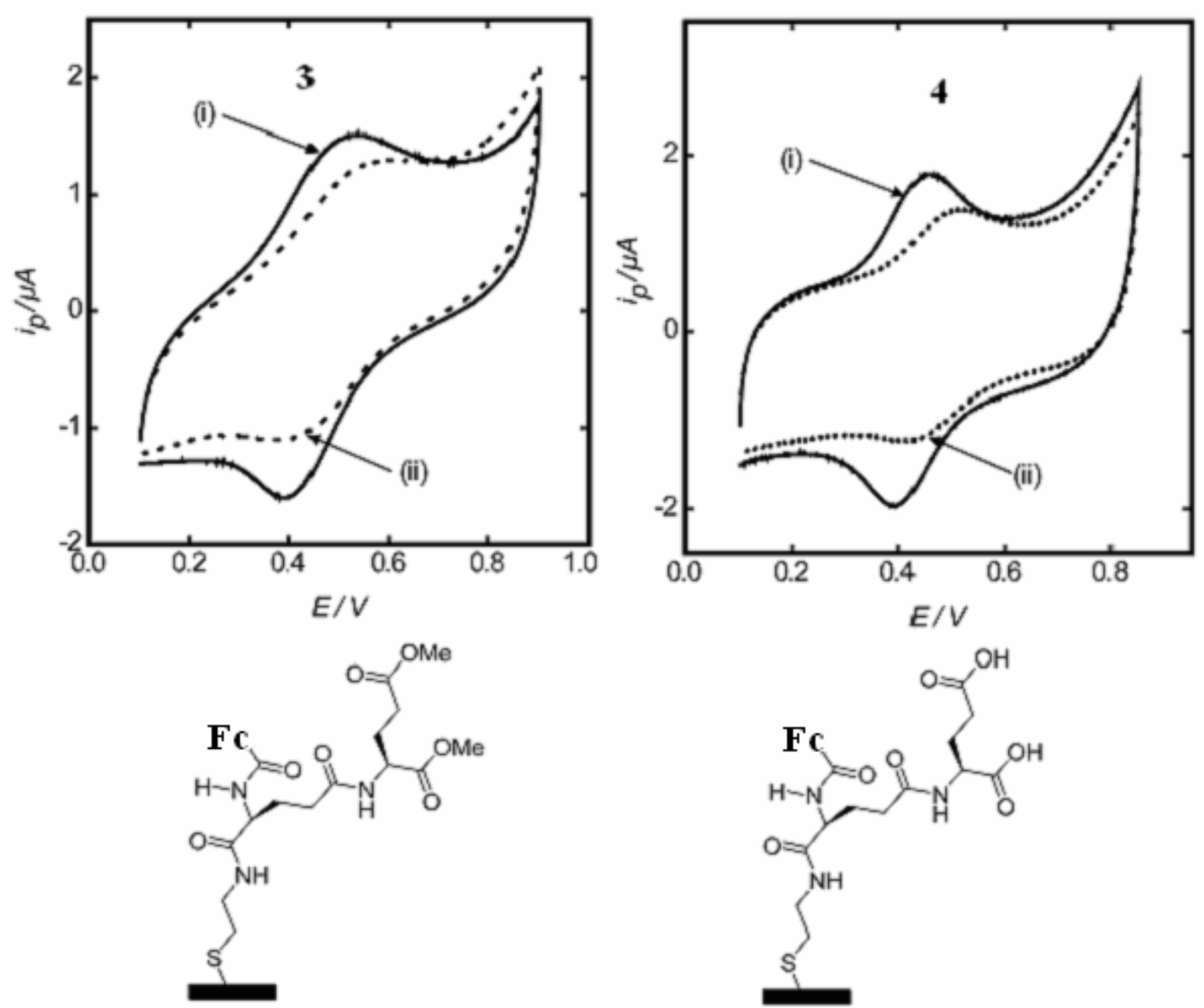

3

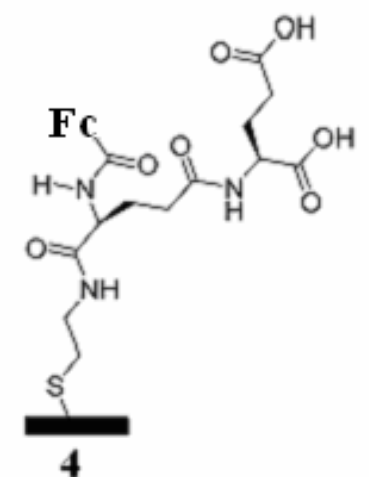

Figure S6. Ion-pair effects (left) films of 3 in $\mathrm{NaClO}_{4}$ (i) and $\mathrm{Na}_{2} \mathrm{SO}_{4}$ (ii). (right) films of 4 in $\mathrm{NaClO}_{4}$ (i) and $\mathrm{Na}_{2} \mathrm{SO}_{4}$ (ii); The characterization conditions consist of a supporting electrolyte $2.0 \mathrm{M}$ at $\mathrm{pH} 7.0 \mathrm{vs} \mathrm{Ag} / \mathrm{AgCl}$.

Blocking studies were carried out on Fc-CO-dendrimer esters and acids modified $\mathrm{Au}$ electrodes in solutions containing $1.0 \mathrm{mM}\left[\mathrm{Fe}(\mathrm{CN})_{6}\right]^{3-/ 4-}$ and $2.0 \mathrm{M} \mathrm{NaClO}_{4}(\mathrm{aq})$ as supporting electrolyte in order to probe the compactness of films. Figure S6 shows the results of the blocking study with $\left[\mathrm{Fe}(\mathrm{CN})_{6}\right]^{3-14-}$ in the absence and in the presence of monolayer films of $\mathbf{1}$ and 2 . In the potential range -0.2 to $0.8 \mathrm{~V}$, both systems showed blocking towards $\left[\mathrm{Fe}(\mathrm{CN})_{6}\right]^{3-4-}$, evident from the lack of signal due to the $\left[\mathrm{Fe}(\mathrm{CN})_{6}\right]^{3-14-}$ redox probe. The only observed redox peak is due to the $\mathrm{Fc} / \mathrm{Fc}^{+}$of the $\mathrm{Fc}-\mathrm{CO}-$ peptide 
dendrimer film. It is however observed that the anodic peak current of $\mathrm{Fc}$ is enhanced in the presence of the $\left[\mathrm{Fe}(\mathrm{CN})_{6}\right]^{3-14-}$ redox probe.

\section{Effect of Anions on the Properties of Fc-CO-Peptide Dendrimer Films:}

Films run in the presence of different electrolytes shows qualitatively similar CV behavior. However, there are quantitative differences. Inorganic anions have been shown to strongly influence ET kinetics rate of Fc terminated monolayers. ${ }^{[\mathrm{a}]}$ It is believed that ion pairing directly influences the stability of the Fc-terminated monolayers and $\Delta E$ is significantly influenced. ${ }^{[b]}$ Perchlorate ions is strongly ion-paired and often used in such studies. $^{[\mathrm{c}]}$ According to Rowe and Creager's model upon oxidation of surface immobilized Fc-dendrimers, anions are required to compensate for the electric charge of the $\mathrm{Fc}^{+}$group. ${ }^{[\mathrm{d}]}$ The model assumes that ther is no ion pairing with the reduced form and that the peak potential shifts accoding to the following equation;

$$
E_{p}=E_{p}^{\prime}-(R T / n F) \ln \left(1+\sum K_{i} c_{i}\right)
$$

where $E_{p}^{\prime}$ is the potential in the absence of the ion pairing, $K_{i}$ is the equilibrium constant between oxidized species and the anion with a bulk concentration of $c_{i}$. To verify the effect of anions on the electrochemical properties of the films of these compounds, CV were recorded in the presence of $\mathrm{NaClO}_{4}$ and $\mathrm{Na}_{2} \mathrm{SO}_{4}$. Table $\mathrm{S} 3$ shows shifts of the $\mathrm{E}_{1 / 2}$, which suggests that $K$ is in the order of $\mathrm{ClO}_{4}{ }^{-}>\mathrm{SO}_{4}{ }^{2-}$. From the viewpoint of the ion pair model, if the counter-ion in the electrolyte solution can form ion pairs with $\mathrm{Fc}^{+}$, the formal potential of the system will shift negatively. A change from $\mathrm{ClO}_{4}{ }^{-}$to $\mathrm{SO}_{4}{ }^{2-}$ ion therefore results in anodic shifts of the potential. 
Table S3. Data comparing electrochemical properties in supporting electrolyte of $2.0 \mathrm{M} \mathrm{NaClO}_{4}$ or $2.0 \mathrm{M} \mathrm{Na}_{2} \mathrm{SO}_{4}$ at $\mathrm{pH} 7.0 . \mathrm{E}^{\circ}$ and $\Delta E$ in $m V$.

\begin{tabular}{ccccc}
\hline & \multicolumn{2}{c}{$\mathrm{ClO}_{4}{ }^{-}$} & \multicolumn{2}{c}{$\left[\mathrm{SO}_{4}\right]^{2-}$} \\
\cline { 2 - 5 } Films & \multicolumn{1}{c}{$E^{o}$} & \multicolumn{1}{c}{$\Delta E$} & $E^{o}$ & $\Delta E$ \\
\hline $\mathbf{1}$ & $467 \pm 25$ & $73 \pm 5$ & $492 \pm 12$ & $103 \pm 15$ \\
$\mathbf{2}$ & $425 \pm 18$ & $47 \pm 5$ & $449 \pm 15$ & $136 \pm 10$ \\
$\mathbf{3}$ & $455 \pm 15$ & $109 \pm 15$ & $478 \pm 15$ & $156 \pm 8$ \\
$\mathbf{4}$ & $424 \pm 15$ & $42 \pm 6$ & $458 \pm 12$ & $102 \pm 10$ \\
\hline
\end{tabular}

The reasons for these observed differences is attributed to the larger free energy of hydration of the $\mathrm{SO}_{4}{ }^{2-}$ ion compared to that of the $\mathrm{ClO}_{4}{ }^{-}$ion which translates into a lower tendency to form ion pairs with $\mathrm{Fc}^{+}$ion. The incorporation of $\mathrm{ClO}_{4}{ }^{-}$ions into $\mathrm{Fc}$ self assembled monolayers induced by the redox reaction has been demonstrated by in situ FT Raman spectrochemistry. ${ }^{[\mathrm{e}]}$ From Nishiyama's work, upon oxidation of the Fc- SAM a band attributed to the $\mathrm{ClO}_{4}{ }^{-}$ion was clearly observed and the peak disappeared in the reduced state. A repeat with $\mathrm{NO}_{3}{ }^{-}$as supporting electrolyte did not show the presence of the ion.

Andreu et al considered ion pairing between electrolyte ions and both the oxidized and reduced adsorbate.[f] Their calculations indicate that when the redox centre is at the end of the adsorbate, the peak potential is dependent on the bulk concentration. Additional evidence for ion pair formation is obtained by monitoring the potential response as a function of added $\mathrm{NaClO}_{4}$. For this titration experiment the ionic strength of the electrolyte was maintained at a high level with a "background electrolyte" concentration of $2.0 \mathrm{M} \mathrm{Na}_{2} \mathrm{SO}_{4}$ (lower ion-pair counterion) and titrated with $\mathrm{NaClO}_{4}$ 
(high ion-pair electrolyte). When the concentration of $\mathrm{ClO}_{4}^{-}$was increased in the presence of $\mathrm{SO}_{4}{ }^{2-}$ the peak potential decreased with increasing concentration as expected from the Nernst equation. A linear relationship is observed between $\mathrm{E}^{\mathrm{o}}$ and the $\log \left[\mathrm{ClO}_{4}^{-}\right]$ (Figure S7) giving a slope $\left(\Delta E^{o} / \Delta \log \left[\mathrm{NaClO}_{4}\right]\right)$ of $51 \pm 7 \mathrm{mV}$ for the $\mathbf{1}$ and $\mathbf{3}$ and about $20 \pm 4 \mathrm{mV}$ for the acids $\mathbf{2}$ and $\mathbf{4}$. The values for the esters $\mathbf{1}$ and $\mathbf{3}$ are close to the theoretical value of $59 \mathrm{mV}$ predicted by the Nernst equation. The small deviation is ascribed to the use of concentrations rather than activities. The values for the acids are lower. Ohtani et al have also publish a theory on the effect of ion pairing which includes double layer effects which allows the interaction of both ion pairing and triple ion formation with the oxidixed adsorbate. ${ }^{[\mathrm{g}]}$

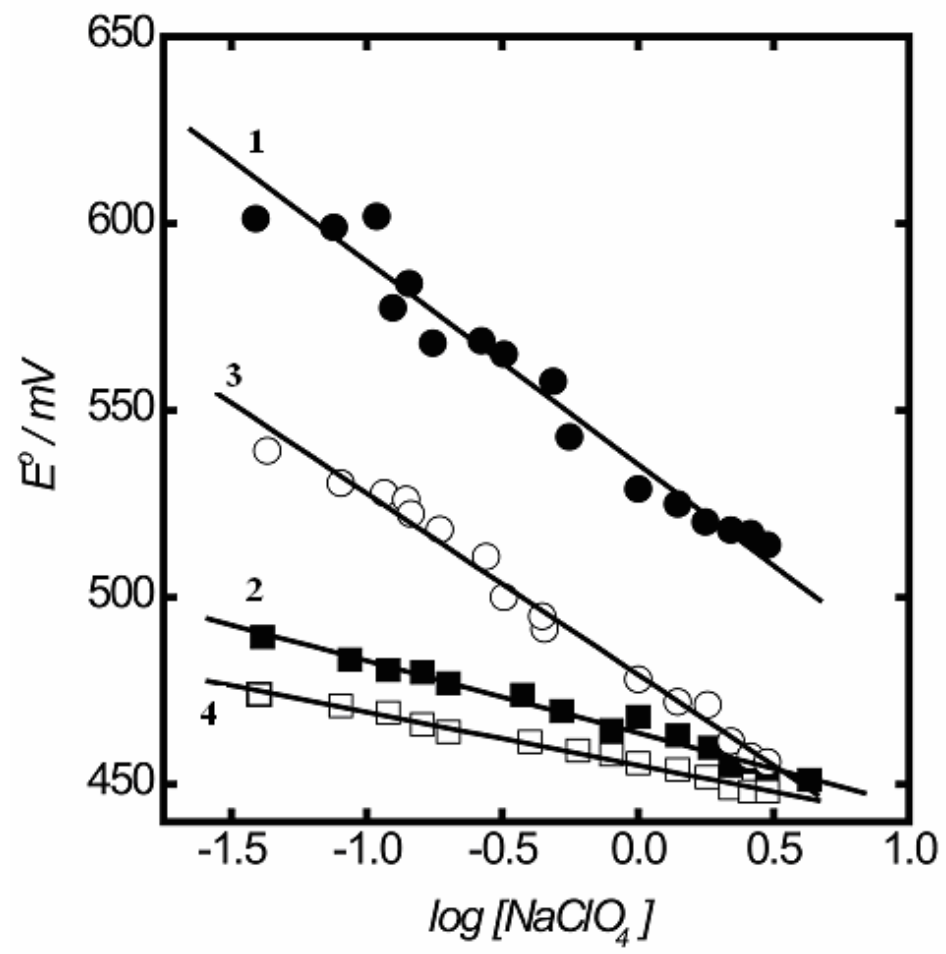

Figure S7. Effect of perchlorate ion on the $\mathrm{E}^{\mathrm{o}}$ of films of 1, 2, 3, and $\mathbf{4}$ on $\mathrm{Au}$ in the presence $2.0 \mathrm{M} \mathrm{Na}_{2} \mathrm{SO}_{4}$, vs $\mathrm{pH}$ 7.0. 
The charge composition of the cation adsorbate by ion pairing is insufficient and therefore there is a net repulsion between the cationic adsorbates. Thus a triple ion that is attracted to the adsorbate is required. CVs that show ion pair formation peaks a usually smaller and broader than in ideal cases but when triple ion formation are involved peaks are shaper and narrow as is observed for the acid films.

From a study of changes of surface charge by AFM at Fc-functionalized aminocarbonyl-sulfonic acid film interfaces, Bard and coworkers showed that the oxidized Fc compensated for the surface negative charge of the sulfonate group which resulted in significant attenuation of charges on the surfaces of the film. ${ }^{[\mathrm{h}]}$ Thus it is strongly suggested that the lower slope values obtained for acid systems are the result of charge neutralization of the interface by the anion and a contribution from the carboxylate terminals by through-space interactions with the $\mathrm{Fc}^{+}{ }^{+[i]}$ The above experiment shows that Fc-functionalized films are significantly influenced by ion-pairing which may control the binding to such interfaces.

[a] Uosaki, K.; Sato, Y.; Kita, H. Langmuir 1991, 7, 1510-1514. Rowe, G. K.; Creager, S. E. Langmuir 1991, 7, 2307-2312.

[b] Shimazu, K.; Sato, Y.; Ye, S.; Uosaki, K. J. Electroanal. Chem. 1994, 375, 409.

[c] Uosaki, K.; Sato, Y.; Kita, H. Langmuir 1991, 7, 1510-1514. Rowe, G. K.; Creager, S. E. Langmuir 1991, 7, 2307-2312, Shimazu, K.; Sato, Y.; Ye, S.; Uosaki, K. J. Electroanal. Chem. 1994, 375, 409; Chidsey, C. E. D. Science 1991, 251, 919-922; Sato, Y.; Mizutani, F.; Shimazu, K.; Ye, S.; Uosaki, K. J. Electroanal. Chem. 1999, 474, 9499.

[d] Uosaki, K.; Sato, Y.; Kita, H. Langmuir 1991, 7, 1510-1514. Rowe, G. K.; Creager, S. E. Langmuir 1991, 7, 2307-2312. 
[e] Nishiyama K., Ueda A., Tanoue S., Koga T., Taniguchi, Chemistry Letts. 2000, 930931; Valincius G., Niaura G., Kazakevičienė B., Talaikytė Z., Kažemėkaitė M., Butkus E., Razumas V., Langmuir 2004, 20, 6631-6638

[f] Andreu R., Calvente J.J., Fewcett W.R., Molero M., J. Phys.Chem B. 1997, 101, 2884.

[g] Ohtani M., Kuwabata S., Yoneyama H, Anal. Chem. 1997, 69, 1045.

[h] Hu, K.; Chai, Z.; Whitesell, J. K.; Bard, A. J. Langmuir 1999, 15, 3343-3347.

[i] Beulen, M. W. J.; Bugler, J.; de Jong, M. R.; Lammerink, B.; Huskens, J.; Schonherr, H.; Vansco, G. J.; Boukamp, B. A.; Wieder, H.; Offenhauserr, A.; Knoll, W.; van Veggel, F. C. J. M.; Reinard, M. D. Chem. Eur. J. 2000, 6, 1176-1183.

\section{XPS: Sulfur signal}

The sulfur signal is of interest because it forms the basis of the covalent formation of the thiolate bond between the S of the CSA and the Au substrate, while the presence of $\mathrm{N}$ and Fe signify the presence of the deposited Fe peptide dendrimers on the Au film. Figure 8 shows the S2p spectra of films of 2 and 4 on Au. The binding enegy of the S-Au is observed at $162 \mathrm{eV}^{[\mathrm{a}]}$ as expected and a minor peak situated at $168-6-168.8 \mathrm{eV}$. The latter peak can not be ascribed to unbound $\mathrm{S}$ which is expected at $164 \mathrm{eV}^{[\mathrm{b}]}$ but assigned to peaks due sulfonates that come from oxidation of species of sulfur on the surface. 

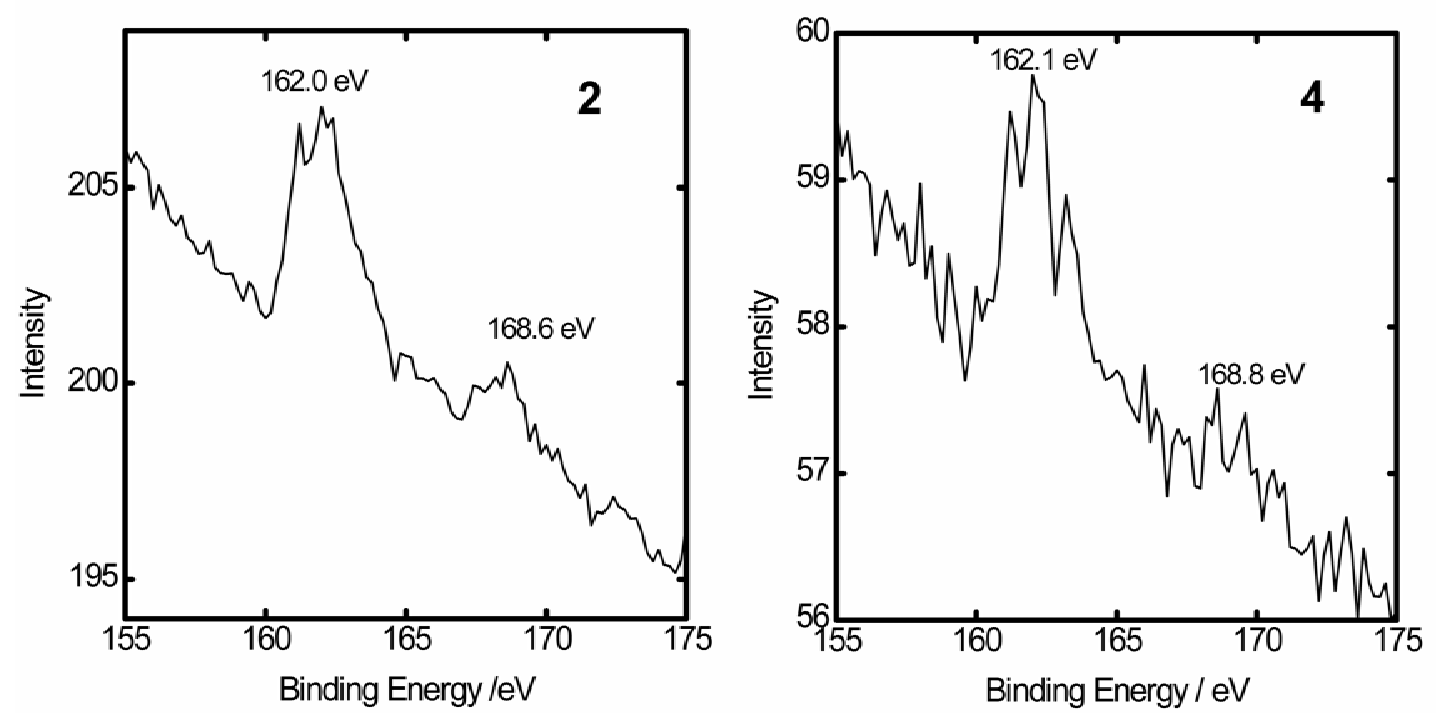

Figure S8. XPS S2p for films 2 and 4 on Au.

[a] Cecchet, F.; Rudolf, P.; Rapino, S.; Margotti, M.; Paolucci, F.; Baggerman, J.; Brouwer, A. M.; Kay, E. R.; Wong, J. K. Y.; Leigh, D. A. J. Phy. Chem. B. 2004, 108, 15192-15199; Cho, Y.; Ivanisevic, A. J. Phys. Chem. B. 2005, 109, 6225-6232; Cecchet, F.; Pilling, M.; Hevesi, L.; Schergna, S.; Wong, J. K. Y.; Clarkson, G. J.; Leigh, D. A.; Rudolf, P. J. Phy. Chem. B. 2003, 107, 10863-10872

[b] Laibinis P.E., Whitesides G.M, Allara D.L., Tao Y., Parikh A.N., Nuzzo R.G.,; J. Am. Soc 1991, 113, 7152. 